\title{
Stir bar-sorptive extraction, solid phase extraction and liquid-liquid extraction for levetiracetam determination in human plasma: comparing recovery rates
}

\author{
Priscila Freitas-Lima ${ }^{1, *}$, Flavia Isaura Santi Ferreira ${ }^{2}$, Carlo Bertucci ${ }^{3}$, Veriano Alexandre Júnior ${ }^{1}$, \\ Sônia Aparecida Carvalho Dreossi ${ }^{2}$, Leonardo Regis Leira Pereira ${ }^{2}$, Américo Ceiki Sakamoto ${ }^{1}$, \\ Regina Helena Costa Queiroz ${ }^{2}$
}

\author{
${ }^{1}$ School of Medicine of Ribeirão Preto, University of São Paulo, Ribeirão Preto, SP, Brazil, ${ }^{2}$ Faculty of Pharmaceutical \\ Sciences of Ribeirão Preto, University of São Paulo, Ribeirão Preto, SP, Brazil, ${ }^{3}$ Department of Pharmacy and Biotechnology, \\ University of Bologna, Bologna, Italy
}

\begin{abstract}
Levetiracetam (LEV), an antiepileptic drug (AED) with favorable pharmacokinetic profile, is increasingly being used in clinical practice, although information on its metabolism and disposition are still being generated. Therefore a simple, robust and fast liquid-liquid extraction (LLE) followed by highperformance liquid chromatography method is described that could be used for both pharmacokinetic and therapeutic drug monitoring (TDM) purposes. Moreover, recovery rates of LEV in plasma were compared among LLE, stir bar-sorptive extraction (SBSE), and solid-phase extraction (SPE). Solvent extraction with dichloromethane yielded a plasma residue free from usual interferences such as commonly co-prescribed AEDs, and recoveries around 90\% (LLE), 60\% (SPE) and 10\% (SBSE). Separation was obtained using reverse phase Select B column with ultraviolet detection $(235 \mathrm{~nm})$. Mobile phase consisted of methanol:sodium acetate buffer $0.125 \mathrm{M} \mathrm{pH} 4.4(20: 80, \mathrm{v} / \mathrm{v})$. The method was linear over a range of 2.8-220.0 $\mu \mathrm{g} \mathrm{mL}^{-1}$. The intra- and inter-assay precision and accuracy were studied at three concentrations; relative standard deviation was less than $10 \%$. The limit of quantification was $2.8 \mu \mathrm{g} \mathrm{mL}^{-1}$. This robust method was successfully applied to analyze plasma samples from patients with epilepsy and therefore might be used for pharmacokinetic and TDM purposes.
\end{abstract}

Uniterms: Levetiracetam/pharmacokinetic. High performance liquid chromatography. Antiepileptic drugs/therapeutic monitoring. Epilepsy/treatment.

Levetiracetam, fármaco antiepiléptico com perfil farmacocinético favorável, tem sido cada vez mais utilizado na prática clínica, embora informações sobre seu metabolismo e disposição cinética ainda estejam sendo geradas. Um método simples, robusto e rápido de extração líquido-líquido seguido por análise por cromatografia líquida de alta eficiência é aqui descrito para servir tanto a investigações farmacocinéticas quanto à monitorização terapêutica. Além disso, as taxas de recuperação do levetiracetam em plasma foram comparadas entre a extração líquido-líquido, a extração sortiva em barra de agitação e a extração em fase sólida. Extração com o solvente diclorometano resultou em plasma livre de interferentes, tais como fármacos antiepilépticos co-prescritos, e apresentou taxas de recuperação em torno de $90 \%$ (extração líquido-líquido), $60 \%$ (extração em fase sólida) e 10\% (extração sortiva em barra de agitação). A separação foi obtida utilizando-se coluna de fase reversa Select B e detecção ultravioleta $(235 \mathrm{~nm})$. A fase móvel foi composta por metanol:tampão acetato de sódio $0,125 \mathrm{M} \mathrm{pH} 4,4$ (20:80, v/v). O método mostrou-se linear para o intervalo de 2,8 a $220,0 \mu \mathrm{g} \mathrm{mL}^{-1}$. Precisão intra- e interdias e a exatidão foram avaliadas em três concentrações; o desvio padrão relativo foi inferior a $10 \%$. O limite de quantificação foi $2.8 \mu \mathrm{g} \mathrm{mL} \mathrm{m}^{-1}$. Este método foi aplicado para análise de amostras de plasma de pacientes com epilepsia e, desta forma, pode ser utilizado satisfatoriamente tanto para fins de farmacocinética quanto de monitorização terapêutica.

Unitermos: Levetiracetam/farmacocinética. Cromatografia líquida de alta eficiência. Antiepiléticos/ monitorização terapêutica. Epilepsia/tratamento.

*Correspondence: P. F. Lima. Hospital das Clínicas. Faculdade de Medicina de Ribeirão Preto. Universidade de São Paulo. Av Bandeirantes, 3900 - $4^{\circ}$ andar CIREP - 14048-900 - Ribeirão Preto - SP, Brasil. E-mail: limapf12@gmail.com 


\section{INTRODUCTION}

Levetiracetam (LEV; $\alpha$-ethyl-2-oxo-1-pyrrolidine acetamide; Figure 1) is an antiepileptic drug (AED) approved by the Food and Drug Administration to be prescribed in polytherapy for management of partial onset seizures with or without secondary generalization in adults and children with refractory epilepsy, and as monotherapy for treatment of partial onset seizures in patients with newly diagnosed epilepsy (Mbizvo et al.,2012; Patsalos, 2004).

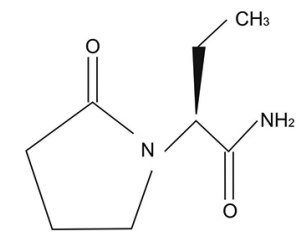

Levetiracetam

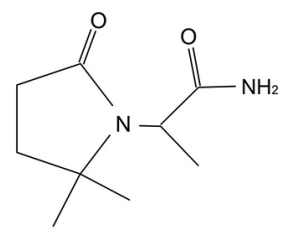

ucb 17025 (internal standard)
FIGURE 1 - Chemical structures of levetiracetam and ucb 17025 (internal standard).

Its innovative mechanism of action based on the selective binding to a synaptic vesicle protein (SV2A) involved in neurotransmitter release (Macdonald; Rogawski, 2008) and the favorable pharmacokinetic profile makes LEV a promising AED in terms of efficacy and tolerability. Levetiracetam presents high oral bioavailability, rapid gastrointestinal absorption $\left(\mathrm{T}_{\mathrm{MAX}}=1 \mathrm{~h}\right)$, linear pharmacokinetics over the therapeutic dosages range $(1000-3000 \mathrm{mg} /$ day $)$, minimal plasma protein binding $(<10 \%)$, and elimination half-life estimated at 6 to $8 \mathrm{~h}$ in adults. According to Strolin Benedetti and colleagues (2003), LEV does not undergo chiral interconversion in humans. In contrast to most other AEDs, LEV elimination is not significantly dependent on the cytochrome $\mathrm{P} 450$ enzymatic system; about $66 \%$ of an oral dose are excreted unchanged in urine, and $24 \%$ undergo hydrolysis in blood to the inactive metabolite ucb L057 (Patsalos, 2004). As a relatively new AED, LEV pharmacokinetics is still under investigation, especially regarding its disposition and elimination in situations such as pregnancy and extremes of ages (Italiano, Perucca, 2013; Tomson, Landmark, Battino, 2013).

Despite the wide reference range for plasma concentration values $(12-46 \mathrm{mg} / \mathrm{L})$ and the positive pharmacokinetic profile, therapeutic drug monitoring (TDM) of LEV is advisable to improve efficacy and safety in special situations, namely pregnancy, renal impairment, in elderly and pediatric patients, to investigate intoxication, therapeutic compliance or overdose (Krasowski, 2010;
Patsalos et al., 2008; Tomson et al., 2007). Several chromatographic methods have been published for quantification of LEV concentrations in biological fluids such as saliva and plasma (or serum) for TDM and in urine for pharmacokinetic aims. They include different subtypes of liquid chromatography with various detection systems (Contin et al., 2008; Grim et al., 2003; Guo et al., 2007; Jain et al., 2006; Juenke et al., 2006; Kuhn, Knabbe, 2013; Lancelin et al., 2007; Martens-Lobenhoffer, BodeBoger, 2005; Matar, 2008; Pucci et al., 2004; Rao et al., 2004; Ratnaraj, Doheny, Patsalos, 1996; Shibata et al., 2012), gas chromatography (Isoherranen et al., 2000; Mecarelli et al., 2007) and microemulsion electrokinetic chromatography (Ivanova et al., 2003). An analytical nonchromatographic method, capillary electrophoresis, is also described (Shihabi, Oles, Hinsdale, 2003). Because of the advantages of high-performance liquid chromatography (HPLC) over other analytical methods, namely in terms of versatility and simplicity of sample preparation, as well as wide linearity range in detectors, relative low cost and widespread use in laboratories, it has become the gold standard method for TDM not only for LEV, but also for all other AEDs monitored (Queiroz et al., 2008).

Different sample pretreatment techniques have been described for LEV analysis, with recoveries ranging from $12 \%$ to $99 \%$, according to the method and reagents. Solidphase extractions (SPE) of LEV performed with different polymeric sorbents such as $\mathrm{C}_{18}$ and hydrophilic-lipophilic balanced copolymer are described in the literature (Isoherranen et al., 2000; Ivanova et al., 2003; Mecarelli et al., 2007; Pucci et al., 2004; Vermeij, Edelbroek, 1994). Protein precipitation is considered a simple, inexpensive and suitable pretreatment procedure especially for drugs minimally bound to plasma proteins. Preparation usually consists of adding organic solvents such as methanol or acetonitrile; formation of insoluble salts through addition of zinc sulphate or perchloric acid is also possible (Contin et al., 2008; Martens-Lobenhoffer, Bode-Boger, 2005; Pucci et al., 2004). Although dilutions can affect the sensitivity of the method, this procedure is considered a positive pretreatment method because LEV is not significantly bound to plasma proteins (Pucci et al., 2004).

Few publications are based on liquid-liquid extraction (LLE) for LEV (Ratnaraj; Doheny; Patsalos, 1996). Although time-consuming and highly dependent on organic solvents, LLE is a feasible and inexpensive method used both for TDM and pharmacokinetics purposes (Chollet, 2002; Isoherranen et al., 2003; Patsalos et al., 2006).

More recently, stir bar-sorptive extraction (SBSE) has been evaluated for the enrichment of organic solutes 
from biological fluids. It is a non-exhaustive sample preparation technique based on the partitioning coefficient of the solutes between the non-polar silicone phase made of polydimethylsiloxane (PDMS) and the aqueous phase. Although this process is still under deeper investigation, it is becoming more popular for different matrices and analytes (David, Sandra, 2007), including therapeutic drugs (Queiroz et al., 2008).

Considering that analytical procedures allowing rapid and robust quantifications of LEV concentrations in biologic fluids are of great interest both for TDM and pharmacokinetic applications, this work aimed to present a study of a reliable analytical method based on comparisons of recovery rates from LLE, SBSE and SPE cleanup procedures followed by HPLC analysis for determination of LEV concentrations in plasma samples. Noteworthy, as the purpose is centered in the comparison of the above-mentioned extraction methods, validation aspects are shown as pertinent.

\section{MATERIAL AND METHODS}

The plasma samples used in the present study were obtained from patients with epilepsy attending the Ribeirão Preto Clinical Hospital. Procedures were performed under written consent and approved by the local Ethics Committee (Approval no 11133/2008).

\section{Instrumentation and reagents}

The analyses were performed on an HPLC system consisting of a Shimadzu LC 10AD pump (Japan), a Shimadzu SPD 10A ultraviolet (UV) detector, a Chromatopac C-R8A integrator (Shimadzu, Columbia, MD, USA) and a Rheodyne injector with a $20 \mu \mathrm{L}$ loop.

Supleco ${ }^{\circledR}$ cartridges $\left(\mathrm{C}_{18}, 3 \mathrm{~mL}\right)$ were used for SPE. The procedure was carried out on a vacuum apparatus (Marconi, Brazil). For SBSE, the commercial stir bar Twister $^{\circledR}$ (10 mm long glass-encapsulated magnetic stir bar externally coated with $22 \mu \mathrm{g}$ of PDMS) was obtained from Gerstel (Gerstel GmbH, Mulheim Ruhr, Germany).

Acetonitrile and dichloromethane (analytical grade) were purchased from Merck KGaA, Darmstadt, Germany. Methanol HPLC grade was obtained from J.T. Baker ${ }^{\circledR}$ HPLC, Mallinckrodt Baker Inc., USA. Sodium acetate anhydrous, sodium hydroxide, di-Natriumtetraborate10-hydrat and glacial acetic acid 100\% anhydrous (for analysis) were obtained from Merck KGaA, Darmstadt, Germany. Deionized water was obtained using a Milli-Q water processing system (Millipore, São Paulo, Brazil). Levetiracetam and the internal standard (IS) ucb 17025
( $\alpha, 2,2$-trimethyl-5-oxo-1-pyrrolidine acetamide; Figure 1) were a kind donation from Prof. Emilio Perucca's lab.

\section{Methods}

\section{Calibration curve}

Stock solutions of LEV in water $\left(0.22 \mathrm{mg} \mathrm{mL}^{-1}\right)$ and of IS in methanol $\left(260.0 \mu \mathrm{mol} \mathrm{L}^{-1}\right)$ were prepared and stored at $-20^{\circ} \mathrm{C}$. These solutions were stable for at least five months. Routine daily calibration curves were prepared for each analytical batch by adding LEV and IS working solutions to drug-free plasma in order to produce LEV concentrations of $7.13,11.88,19.8,33.0$ and $55.0 \mu \mathrm{g} \mathrm{mL} \mathrm{L}^{-1}$.

\section{Analytical conditions}

Chromatographic separation was achieved isocratically, at room temperature, using an analytical column (250x4 mm i.d.) with precolumn $(4 \times 4 \mathrm{~mm})$ packed with LiChrospher 60 RP-select B, $5 \mu \mathrm{m}$ particle size $\left(\right.$ Merck $\left.^{\circledR}\right)$. Mobile phase consisted of a mixture of methanol and sodium acetate buffer $0.125 \mathrm{M}, \mathrm{pH} 4.4$ $(20: 80, \mathrm{v} / \mathrm{v})$ daily prepared and degassed. The mobile phase was delivered into the HPLC system at a flow-rate of $1.0 \mathrm{~mL} \mathrm{~min}^{-1}$. The UV detector was set at $235 \mathrm{~nm}$.

\section{Sample preparation for SPE}

The SPE cartridge was conditioned with $2 \mathrm{~mL}$ of methanol followed by $2 \mathrm{~mL}$ of water. A mixture of $100 \mu \mathrm{L}$ of plasma with $25 \mu \mathrm{L}$ of IS and $3 \mathrm{~mL}$ of borate buffer $(0.1 \mathrm{M}, \mathrm{pH} 9.0)$ was mixed in a vortex-type shaker for $1 \mathrm{~min}$, and loaded into the cartridges which were previously dried under low vacuum at room temperature. The cartridges were then washed with $5 \mathrm{~mL}$ of water and dried under vacuum for $5 \mathrm{~min}$. Elution was performed with $2 \mathrm{~mL}$ of dichloromethane under low vacuum at room temperature. The eluate was transferred into conic tubes to be evaporated under constant airflow. The dry residue was reconstituted in $50 \mu \mathrm{L}$ of the mobile phase and, after vortexing for $10 \mathrm{~s}, 20 \mu \mathrm{L}$ were injected into the HPLC system.

\section{Sample preparation for SBSE}

Prior to first use, the stir bar was placed into a vial containing acetonitrile and conditioned for $24 \mathrm{~h}$. A mixture of $100 \mu \mathrm{L}$ of plasma sample with $3 \mathrm{~mL}$ of borate buffer $(0.1$ $\mathrm{M}, \mathrm{pH} 9.0$ ) and $25 \mu \mathrm{L}$ of IS was vortexed for $1 \mathrm{~min}$ at room temperature. The stir bar was immersed into the sample and the extraction was performed under a magnetic stirring rate of $1200 \mathrm{rpm}$ for $30 \mathrm{~min}$ at $50{ }^{\circ} \mathrm{C}$. For desorption, the stir bar was firstly removed with tweezers, carefully dried in clean tissue and put in a glass tube containing $2 \mathrm{~mL}$ of 
dichloromethane, ensuring total immersion. Desorption was performed under a magnetic stirring rate of $1200 \mathrm{rpm}$ for $30 \mathrm{~min}$ at $50^{\circ} \mathrm{C}$. After the desorption step, the stir bar was removed by means of a magnetic rod and the solvent was evaporated to dryness at room temperature under airflow. The dry residue was reconstituted in $50 \mu \mathrm{L}$ of mobile phase and $20 \mu \mathrm{L}$ were injected into the HPLC system after shaking for $10 \mathrm{~s}$ in a vortex-type shaker. After each the successive extraction the used stir bar was cleaned in methanol for $30 \mathrm{~min}$ at $50^{\circ} \mathrm{C}$ (under a magnetic stirring rate of $1200 \mathrm{rpm})$, followed by a drying step using a lint-free tissue.

\section{Sample preparation for LLE}

Liquid-liquid extraction was based on that previously proposed by Ratnaraj, Doheny and Patsalos (1996) with minor modifications herein described. Twenty five microliters of IS were added to $25 \mu \mathrm{L}$ of $\mathrm{NaOH} 5 \mathrm{M}$, $2 \mathrm{~mL}$ of dichloromethane and $100 \mu \mathrm{L}$ of plasma. The mixture was shaken in a vortex-type shaker for $1 \mathrm{~min}$ and then centrifuged at $1800 \mathrm{rpm}$ for $5 \mathrm{~min}$. The organic phase was transferred to conic tubes and evaporated under constant airflow at room temperature. The dry residue was reconstituted in $50 \mu \mathrm{L}$ of mobile phase and, after shaking for $10 \mathrm{~s}$ in a vortex-type shaker, $20 \mu \mathrm{L}$ were injected into the HPLC system.

\section{HPLC method validation}

Recovery rates were determined at the five different concentrations from the calibration curve. Levetiracetam was extracted in triplicate from human blank plasma according to each method proposed above and the UVpeak heights were compared to the direct injection of standard solutions of equal concentrations.

In order to obtain intra- and inter-assay precisions, aliquots ( $\mathrm{n}=10$ and $\mathrm{n}=5$, respectively) of blank plasma containing LEV and IS at three different concentrations were analyzed. The inter-assay precision was determined based on analyses of blank plasma containing LEV and IS solutions at the same three concentrations for five consecutive days. Accuracy was checked using three concentrations within the linear range of the procedure. The accuracy values accepted showed variations of less than $15 \%$.

Linearity was determined by analyzing drug-free plasma samples $(n=3)$ containing LEV and IS solutions at concentrations from 2.85 to $220.0 \mu \mathrm{g} \mathrm{mL}^{-1}$, a range wide enough to cover the routine calibration curve (from 7.13 to $\left.55.0 \mu \mathrm{g} \mathrm{mL}^{-1}\right)$. The concentration range was estimated based on the regression curve $(y=a x+b)$ and correlation coefficient $\left(R^{2}\right)$.

The limit of quantification (LOQ) was determined by analyzing drug-free plasma samples spiked with decreasing concentrations of LEV standard solution. The LOQ was considered the lowest concentration quantified with a relative standard deviation (RSD) of less than $10 \%$, obtained from five determinations.

\section{RESULTS}

Table I displays the concentration range to which linearity was determined, the regression curve and correlation coefficient referred to the range, and the comparison of LEV recovery rates from the different extraction procedures evaluated.

Validation parameters for LLE are shown in Table II. Figure 2 displays representative chromatograms from the validated method applied to clinical samples.

\section{DISCUSSION}

Three different sample preparation procedures were tested and compared for LEV extraction from human plasma. Recovery rates were assumed as the most important figure of merit in comparing the cleanup procedures, i.e., methods with low recovery rates $(<80 \%)$

TABLE I - Comparison of LEV recovery rates from the different extraction procedures

\begin{tabular}{|c|c|c|c|c|c|c|}
\hline \multirow{3}{*}{$\begin{array}{l}\text { LEV conc. } \\
\left(\mu \mathrm{g} \cdot \mathrm{mL}^{-1}\right)\end{array}$} & \multirow{3}{*}{ Linear regression; $R^{2}$} & \multirow{3}{*}{$\begin{array}{c}\text { Limit of } \\
\text { quantification } \\
\left(\mu \mathrm{g} \cdot \mathrm{mL}^{-1}\right)\end{array}$} & \multicolumn{4}{|c|}{ Absolute recoveries } \\
\hline & & & \multirow{2}{*}{$\begin{array}{l}\text { Evaluated conc. } \\
\quad\left(\mu \mathrm{g} \cdot \mathrm{mL}^{-1}\right)\end{array}$} & \multicolumn{3}{|c|}{ Results (\%) } \\
\hline & & & & LLE & SPE & SBSE \\
\hline \multirow[t]{5}{*}{$2.85-220.0$} & \multirow{5}{*}{$\begin{array}{c}\mathrm{y}=0.0245 \mathrm{x}+0.1842 \\
0.991\end{array}$} & \multirow[t]{5}{*}{2.85} & 7.1 & 90.2 & 60.7 & 11.6 \\
\hline & & & 11.9 & 92.5 & 61.9 & 11.0 \\
\hline & & & 19.8 & 91.1 & 59.7 & 12.2 \\
\hline & & & 33.0 & 89.7 & 60.2 & 10.1 \\
\hline & & & 55.0 & 87.1 & 60.4 & 10.0 \\
\hline
\end{tabular}

LEV: levetiracetam; LLE: liquid-liquid extraction; SBSE: stir bar-sorptive extraction; SPE: solid phase extraction. 
TABLE II - Intra- and inter-assay precision and accuracy data for LEV according to the validated method

\begin{tabular}{|c|c|c|c|}
\hline $\begin{array}{l}\text { LEV conc. } \\
\left(\mu \mathrm{g} \cdot \mathrm{mL}^{-1}\right)\end{array}$ & $\begin{array}{c}\begin{array}{c}\text { Precision Intra-assay RSD (\%) } \\
\mathrm{n}=\mathbf{1 0}\end{array} \\
\end{array}$ & $\begin{array}{c}\begin{array}{c}\text { Precision Inter-assay RSD (\%) } \\
n=5\end{array} \\
\end{array}$ & Accuracy error $(\%)$ \\
\hline 13.0 & 5.4 & 5.0 & 4.9 \\
\hline 15.0 & 6.0 & 5.0 & 9.6 \\
\hline 30.0 & 7.0 & 6.6 & 3.8 \\
\hline
\end{tabular}

RSD: relative standard deviation; LEV: levetiracetam.

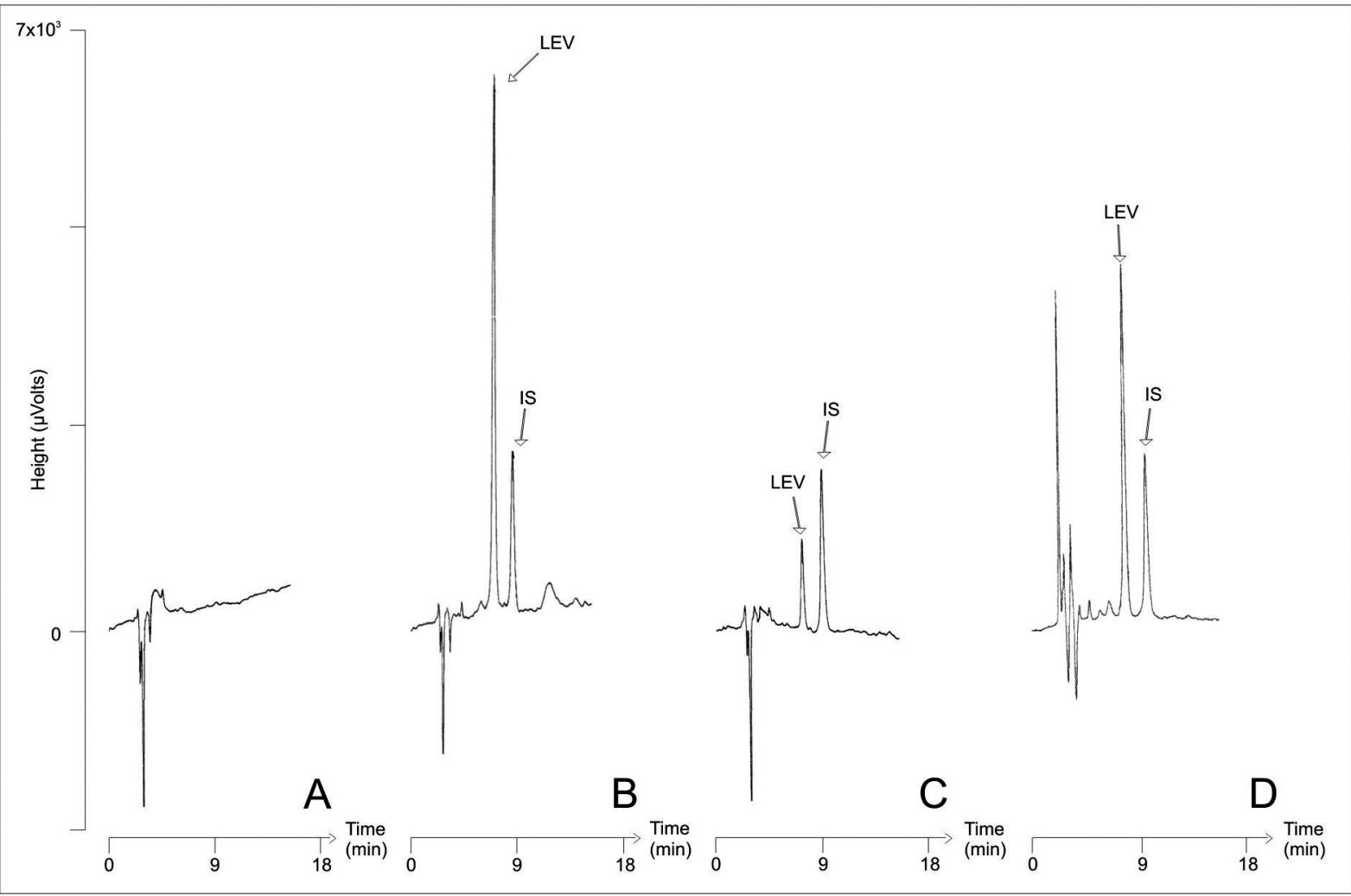

FIGURE 2 - Chromatograms from the validated method. (A): drug-free plasma sample (blank); (B): plasma spiked with LEV and IS to the final LEV concentration of $55 \mu \mathrm{g} \mathrm{mL}^{-1}$; (C): clinical sample from an adult patient with epilepsy on lamotrigine chronic treatment $(200 \mathrm{mg} /$ day) obtained 9 hours after the ingestion of a LEV single dose $(1000 \mathrm{mg})$; (D): clinical sample from an adult patient with epilepsy on carbamazepine chronic treatment $(600 \mathrm{mg} /$ day) obtained 1 hour after the ingestion of a LEV single dose (1000 mg). IS: internal standard; LEV: levetiracetam.

were considered unsatisfactory for our aims and eventually were not validated. Although recovery rate was the most important parameter in determining the validity of the method, other aspects such as complexity of execution, time-consumption and amounts of organic solvents required were also balanced in order to discuss the most suitable method for TDM and pharmacokinetic aims.

The stationary phase $\left(\mathrm{C}_{18}\right)$ here selected for SPE analyses is considered a reasonable choice according to Isoherranen and colleagues (2000), Ivanova and colleagues (2003), Vermeij and Edelbroek ( 1994) and Chollet (2002), although Pucci and co-workers (2004) argue against the reproducibility of the results obtained from this sorbent among different batches. Considering the high hydrophilic characteristic of LEV, our present elution performed with dichloromethane can possibly explain the low recovery rates found (Table I) and to what is reported elsewhere (Isoherranen et al., 2000; Pucci et al., 2004; Vermeij,Edelbroek, 1994; Zufia et al., 2010). Among the organic solvents commonly used in SPE, dichloromethane has a polarity index of 3.4 , while it is 6.6 for methanol. This is suggestive that mixtures with higher polarity indexes such as acetonitrile and methanol (Zufia et al., 2010) or methanol and water (Vermeij, 
Edelbroek, 1994) would extract LEV from stationary phase efficiently. Despite the main advantages of SPE, namely the purification and enrichment of analytes from complex matrices and the use of low amounts of organic solvents, it is an expensive and time-consuming procedure, not reliable especially for analyses of large amounts of samples as in pharmacokinetic studies and routine TDM analyses. Furthermore, in our specific case, the low recovery rates found would not be suitable for neither pharmacokinetics nor for TDM purposes.

To our knowledge, no publication in the literature has tried to extract LEV from any matrix using SBSE. This extraction method has proven to be an interesting and environmentally friendly alternative to LLE considering its insignificant organic solvent consumption and higher limits of detection (David, Sandra, 2007). However, the even lower recovery rates obtained from SBSE (Table I) make this procedure a non-suitable cleanup method. As bars with different coatings other than PDMS are released, this method could be optimized for extracting LEV from human plasma.

Liquid-liquid extraction modified from Ratnaraj and co-workers (Ratnaraj; Doheny; Patsalos, 1996) proved to be the most satisfactory of the evaluated methods. Due to the high recovery rates (Table I), validation parameters were established only for LLE, as illustrated in Table II. The LOQ found was $2.85 \mu \mathrm{g} \mathrm{mL}^{-1}$. Calibration curves were linear in the range of 2.85-220.0 $\mathrm{g} \mathrm{mL}^{-1}$, with $R^{2}=0.991$. Linear regression equation was defined as $y=0.0245 x+0.1842$. Accuracy and intra- and interassay precision were studied at three concentrations, as summarized in Table II. The RSD were less than $10 \%$.

The small amount of biological matrix needed $(100 \mu \mathrm{L})$ makes this a suitable method even for children. The pretreatment steps presented here are free of toxic solvents such as petroleum ether and chloroform (Isoherranen et al., 2003) and provided results without any interference from drugs normally used with no prescription. Accordingly, there were no interfering peaks related to endogenous nor exogenous compounds, as can be observed on the chromatograms (Figure 2), where drugfree human plasma, spiked human plasma and clinical samples from patients with epilepsy show the ability of the method to quantify LEV unequivocally.

Several mobile phases were tested and the proposed (methanol:sodium acetate buffer $0.125 \mathrm{M}, \mathrm{pH}$ 4.4, 20:80 $\mathrm{v} / \mathrm{v}$ ) was the simplest that yielded satisfactory separation in a acceptable run time with retention times of $6.5 \mathrm{~min}$ for LEV and $8.0 \mathrm{~min}$ for IS (Figure 2). The complete elution was obtained in less than $20 \mathrm{~min}$ through isocratic mode, in contrast to Vermeij and Edelbroek ( 1994) and
Martens-Lobenhoffer and Bode-Boger ( 2005) who performed gradient runs for their analyses. Remarkably, the isocratic mode of elution is still the preferred choice when compared to gradient elution, possibly because of improvements in column efficiencies as well as issues related to equilibration time, throughput, ease of use and availability of suitable pumps (Chollet, 2002).

Solvent extraction with $\mathrm{NaOH}$ and dichloromethane, the mobile phase described, and detection at $235 \mathrm{~nm}$ showed high sensitivity and resolution for detection of LEV in human plasma. Different wavelengths between 205 and $240 \mathrm{~nm}$ were tested. Considering that real clinical samples can be difficult to yield chromatographic peak separations because of comedications and endogenous interferences, a high wavelength set at $235 \mathrm{~nm}$ showed to be the best for selectivity instead of the UV detection at $205 \mathrm{~nm}$ (very unspecific) described elsewhere (Contin et al., 2008; Martens-Lobenhoffer, Bode-Boger, 2005; Pucci et al., 2004; Zufia et al., 2010).

The polytherapies frequently prescribed to approximately one third of all patients with epilepsy who do not achieve satisfactory seizure control with currently available AEDs in monotherapy (Sander, 2003) often include drugs such as carbamazepine, phenytoin, phenobarbital and benzodiazepines. Figures $2 \mathrm{C}$ and 2D illustrate the selectivity of the method on two plasma sample chromatograms, as they show the absence of interfering peaks of lamotrigine (2C) and carbamazepine (2D), two commonly used AEDs, in LEV and IS analyses. Chromatograms shown in Figure 2C and 2D were obtained from adult patients with epilepsy chronically treated with lamotrigine $200 \mathrm{mg}$ /day and carbamazepine $600 \mathrm{mg}$ /day, respectively, after receiving a single oral dose of LEV $1000 \mathrm{mg}$. Although no reference range has been definitely established for LEV, clinical studies published using adult patients with epilepsy show LEV plasma concentrations mostly ranging from 12 to $46 \mu \mathrm{g} \mathrm{mL}^{-1}$ (Patsalos et al., 2008), values fully in accordance with our proposed quantification range.

\section{CONCLUSIONS}

This paper presents a simple, robust and fast method for determination of LEV in human plasma using reverse-phase HPLC combined with UV detection. The method is compatible with pharmacokinetic studies and TDM. Based on figures of merit results, the LLE procedure proved to be adequate to LEV analyses from sub-therapeutic to toxic levels. The assay was successfully applied to the analysis of real samples once it could be considered selective, especially for patients with epilepsy 
in chronic treatment with AEDs other than LEV. Taken into account that the core of the present study is the methods comparison essentially based on their recovery rates, LLE was considered a shorter step, precise and an inexpensive sample preparation method to be routinely used instead of the other methods evaluated.

\section{ACKNOWLEDGMENTS}

The authors would like to thank the Conselho Nacional de Desenvolvimento Científico e Tecnológico (CNPq, Brazil) and the Coordenação de Aperfeiçoamento de Pessoal de Nível Superior (CAPES, Brazil) for the financial support.

\section{REFERENCES}

CHOLLET, D. F. Determination of antiepileptic drugs in biological material. J. Chromatogr. B, v.767, n.2, p.191233, 2002.

CONTIN, M.; MOHAMED, S.; ALBANI, F.; RIVA, R.; BARUZZI, A. Simple and validated HPLC-UV analysis of levetiracetam in deproteinized plasma of patients with epilepsy. J. Chromatogr. B, v.873, n.1, p.129-132, 2008.

DAVID, F.; SANDRA, p.Stir bar sorptive extraction for trace analysis. J. Chromatogr. A, v.1152, n.1-2, p.54-69, 2007.

GRIM, S. A.; RYAN, M.; MILES, M. V. ; TANG, p.H.; STRAWSBURG, R. H.; DEGRAUW, T. J.; FAKHOURY, T. A.; BAUMANN, R. J. Correlation of levetiracetam concentrations between serum and saliva. Ther. Drug Monit., v.25, n.1, p.61-66, 2003.

GUO, T.; OSWALD, L. M.; MENDU, D. R.; SOLDIN, S. J. Determination of levetiracetam in human plasma/serum/ saliva by liquid chromatography-electrospray tandem mass spectrometry. Clin. Chim. Acta, v.375, n.1-2, p.115-118, 2007.

ISOHERRANEN, n.; ROEDER, M.; SOBACK, S.; YAGEN, B.; SCHURIG, v.; BIALER, M. Enantioselective analysis of levetiracetam and its enantiomer R-alpha-ethyl-2-oxopyrrolidine acetamide using gas chromatography and ion trap mass spectrometric detection. J. Chromatogr. B, v.745, n.2, p.325-332, 2000.
ISOHERRANEN, n.; SPIEGELSTEIN, O.; BIALER, M.; ZHANG, J.; MERRIWEATHER, M.; YAGEN, B.; ROEDER, M.; TRIPLETT, A. A.; SCHURIG, v.; FINNELL, R. H. Developmental outcome of levetiracetam, its major metabolite in humans, 2-pyrrolidinone $\mathrm{N}$-butyric acid, and its enantiomer (R)-alpha-ethyl-oxo-pyrrolidine acetamide in a mouse model of teratogenicity. Epilepsia, v.44, n.10, p.1280-1288, 2003.

ITALIANO, D.; PERUCCA, E. Clinical pharmacokinetics of new-generation antiepileptic drugs at the extremes of age: an update. Clin. Pharmacokinet., v.52, n.8, p.627-645, 2013.

IVANOVA, M.; PIUNTI, A.; MARZIALI, E.; KOMAROVA, N.; RAGGI, M. A.; KENNDLER, E. Microemulsion electrokinetic chromatography applied for separation of levetiracetam from other antiepileptic drugs in polypharmacy. Electrophoresis, v.24, n.6, p.992-998, 2003.

JAIN, D. S.; SUBBAIAH, G.; SANYAL, M.; PAL, U.; SHRIVASTAV, p.S. Determination of levetiracetam in human plasma by liquid chromatography/electrospray tandem mass spectrometry and its application to bioequivalence studies. Rapid Commun. Mass Spectrom., v.20, n.17, p.2539-2547, 2006.

JUENKE, J.; BROWN, p.I.; URRY, F. M.; MCMILLIN, G. A. Drug monitoring and toxicology: a procedure for the monitoring of levetiracetam and zonisamide by HPLC-UV. J. Anal. Toxicol., v.30, n.1, p.27-30, 2006.

KRASOWSKI, M. D. Therapeutic Drug Monitoring of the Newer Anti-Epilepsy Medications. Pharmaceuticals (Basel), v.3, n.6, p.1909-1935, 2010.

KUHN, J.; KNABBE, C. Fully validated method for rapid and simultaneous measurement of six antiepileptic drugs in serum and plasma using ultra-performance liquid chromatography-electrospray ionization tandem mass spectrometry. Talanta, v.110, p.71-80, 2013.

LANCELIN, F.; FRANCHON, E.; KRAOUL, L.; GARCIAU, I.; BROVEDANI, S.; TABAOUTI, K.; LANDRE, E.; CHASSOUX, F.; PAUBEL, p.; PIKETTY, M. L. Therapeutic drug monitoring of levetiracetam by highperformance liquid chromatography with photodiode array ultraviolet detection: preliminary observations on correlation between plasma concentration and clinical response in patients with refractory epilepsy. Ther. Drug. Monit., v.29, n.5, p.576-583, 2007. 
MACDONALD, R. L.; ROGAWSKI, M. A. Cellular effects of antiepileptic drugs. In: ENGEL, J.; PEDLEY, T.A. (Eds.). Epilepsy: a comprehensive textbook. 2.ed. Philadelphia: Lippincott Williams and Wilkins, 2008. p.1433-1447.

MARTENS-LOBENHOFFER, J.; BODE-BOGER, S. M. Determination of levetiracetam in human plasma with minimal sample pretreatment. J. Chromatogr. B, v.819, n.1, p.197-200, 2005.

MATAR, K. M. Quantification of levetiracetam in human plasma by liquid chromatography-tandem mass spectrometry: application to therapeutic drug monitoring. J. Pharm. Biomed. Anal., v.48, n.3, p.822-828, 2008.

MBIZVO, G. K.; DIXON, p.; HUTTON, J. L.; MARSON, A. G. Levetiracetam add-on for drug-resistant focal epilepsy: an updated Cochrane Review. Cochrane Database of Systematic Reviews, v.9, 2012.

MECARELLI, O.; LI VOTI, p.; PRO, S.; ROMOLO, F. S.; ROTOLO, M.; PULITANO, p.; ACCORNERO, n.; VANACORE, n.Saliva and serum levetiracetam concentrations in patients with epilepsy. Ther. Drug Monit., v.29, n.3, p.313-318, 2007.

PATSALOS, p.N. Clinical pharmacokinetics of levetiracetam. Clin. Pharmacokinet., v.43, n.11, p.707-724, 2004.

PATSALOS, p.N. ; BERRY, D. J.; BOURGEOIS, B. F.; CLOYD, J. C.; GLAUSER, T. A.; JOHANNESSEN, S. I.; LEPPIK, I. E.; TOMSON, T.; PERUCCA, E. Antiepileptic drugs-best practice guidelines for therapeutic drug monitoring: a position paper by the subcommission on therapeutic drug monitoring, ILAE Commission on Therapeutic Strategies. Epilepsia, v.49, n.7, p.1239-1276, 2008.

PATSALOS, p.N. ; GHATTAURA, S.; RATNARAJ, n.; SANDER, J. W. In situ metabolism of levetiracetam in blood of patients with epilepsy. Epilepsia, v.47, n.11, p.1818-1821, 2006.

PUCCI, v.; BUGAMELLI, F.; MANDRIOLI, R.; FERRANTI, A.; KENNDLER, E.; RAGGI, M. A. High-performance liquid chromatographic determination of Levetiracetam in human plasma: comparison of different sample clean-up procedures. Biomed. Chromatogr., v.18, n.1, p.37-44, 2004.
QUEIROZ, R. H.; BERTUCCI, C.; MALFARA, W. R.; DREOSSI, S. A.; CHAVES, A. R.; VALERIO, D. A.; QUEIROZ, M. E. Quantification of carbamazepine, carbamazepine-10,11-epoxide, phenytoin and phenobarbital in plasma samples by stir bar-sorptive extraction and liquid chromatography. J. Pharm. Biomed. Anal., v.48, n.2, p.428434, 2008.

RAO, B. M.; RAVI, R.; SHYAM SUNDAR REDDY, B.; SIVAKUMAR, S.; GOPI CHAND, I.; PRAVEEN KUMAR, K.; ACHARYULU, p.V. ; OM REDDY, G.; SRINIVASU, M. K. A validated chiral LC method for the enantioselective analysis of Levetiracetam and its enantiomer R-alpha-ethyl-2-oxo-pyrrolidine acetamide on amylose-based stationary phase. J. Pharm. Biomed. Anal., v.35, n.5, p.1017-1026, 2004.

RATNARAJ, n.; DOHENY, H. C.; PATSALOS, p.N. A micromethod for the determination of the new antiepileptic drug levetiracetam (ucb LO59) in serum or plasma by high performance liquid chromatography. Ther. Drug Monit., v.18, n.2, p.154-157, 1996.

SANDER, J. W. The epidemiology of epilepsy revisited. Curr. Opin. Neurol., v.16, n.2, p.165-170, 2003.

SHIBATA, M.; HASHI, S.; NAKANISHI, H.; MASUDA, S.; KATSURA, T.; YANO, I. Detection of 22 antiepileptic drugs by ultra-performance liquid chromatography coupled with tandem mass spectrometry applicable to routine therapeutic drug monitoring. Biomed. Chromatogr., v.26, n.12, p.1519-1528, 2012.

SHIHABI, Z. K.; OLES, K.; HINSDALE, M. Analysis of the antiepileptic drug keppra by capillary electrophoresis. $J$. Chromatogr. A, v.1004, n.1-2, p.9-12, 2003.

STROLIN BENEDETTI, M.; WHOMSLEY, R.; NICOLAS, J. M.; YOUNG, C.; BALTES, E. Pharmacokinetics and metabolism of 14C-levetiracetam, a new antiepileptic agent, in healthy volunteers. Eur. J. Clin. Pharmacol., v.59, n.8-9, p.621-630, 2003.

TOMSON, T.; LANDMARK, C. J.; BATTINO, D. Antiepileptic drug treatment in pregnancy: changes in drug disposition and their clinical implications. Epilepsia, v.54, n.3, p.405414, 2013. 
TOMSON, T.; PALM, R.; KALLEN, K.; BEN-MENACHEM, E.; SODERFELDT, B.; DANIELSSON, B.; JOHANSSON, R.; LUEF, G.; OHMAN, I. Pharmacokinetics of levetiracetam during pregnancy, delivery, in the neonatal period, and lactation. Epilepsia, v.48, n.6, p.1111-1116, 2007.

VERMEIJ, T. A.; EDELBROEK, p.M. High-performance liquid chromatographic and megabore gas-liquid chromatographic determination of levetiracetam (ucb L059) in human serum after solid-phase extraction. J. Chromatogr. B, v.662, n.1, p.134-139, 1994.
ZUFIA, L.; ALDAZ, A.; IBANEZ, n.; GIRALDEZ, J.; VITERI, C. LC method for therapeutic drug monitoring of levetiracetam: evaluation of the assay performance and validation of its application in the routine area. Clin. Biochem., v.43, n.4-5, p.473-482, 2010.

Received for publication on $10^{\text {th }}$ April 2014 Accepted for publication on $02^{\text {nd }}$ November 2014 
